九州大学学術情報リポジトリ

Kyushu University Institutional Repository

\title{
Egg-Laying Habits of A Spinach Leaf-Miner, Pegomyia Hyoscyami Panzer (Diptera)
}

Yasumatsu, Keizo

Entomological Laboratory, Department of Agriculture, Kyushu University

Sasagawa, Mitsuhiro

https://doi.org/10.5109/22652

出版情報：九州大学大学院農学研究院紀要. 10 (2)，pp. 169-183，1953-09. Kyushu University バージョン:

権利関係 : 


\begin{abstract}
Journal of the Faculty of Agriculture, Kyūshū University, Vol, 10, No. 2 September 30, 1953
\end{abstract}

\title{
EGG-LAYING HABITS OF A SPINACH LEAF-MINER, PEGOMYIA HYOSCYAMI PANZER (Diptera)
}

\author{
Keizô Yasumatsu and Mitsuhiro Sasagawa
}

\section{INTRODUCTION}

The first published record of the infestation of spinach by Pegomyia hyoscyami Panzer in Japan is found in a booklet made by Oda and Takimoto (1939), in which the fly is reported in Fukuoka Prefecture. In view of the widespread existence and abundance of the fly in Northern Kyushu since 1939, there is reason to believe that it increased markedly some time before that year. The senior author assumes that this increase may chiefly be attributed to the cultivation of some European and Chinese races of spinach. Before the cultivation of such spinaches, several weeds of the family Chenopodiaceae were the only preferred host plants to this fly. Thus, a serious menace to the successful cultivation of spinach in almost all the spinach growing areas came to the senior author's attention in 1943, leading to observations on the bionomics of the fly. The present report is a part of the authors' investigations which were made during 1943 to 1947 near and in the campus of Kyushu University, Fukuoka.

This opportunity is taken to acknowledge the kind guidance given by Professor Teiso Esaki of Kyushu University. Acknowledgment is also due to Dr. Satoru Kuwayama, of the Hokkaido Agricultural Experiment Station, for his kindness in literature. Much credit is also due Professor Hajime Yoshii for his kind suggestion and Mr. Kazuo Yasutomi for his helpful assistance in material. 


\section{DEgREE OF INFESTATION OR THE NUMBER OF EgGS DePOSITED on a Single Host Plan'T}

Experience in previous years and observations in 1943 indicated that 100 per cent loss of spinach occurred even if one egg of Pegomyia hyoscyami was deposited on every leaf of spinach plant. In Table 1 are shown some samples of completely damaged spinach plants observed in a spinach area near the campus of Kyushu University in the spring of 1945. Spinach plant No. 1 has 53 leaves with as many eggs as 449 . This figure highly exceeds the highest record of Kemner (1925) who observed one sugar beet habouring 304 eggs in Sweden. As seen in Table 1, the number of eggs per leaf ranged from 6.3 to 11.3. Such state of high egg populations would indicate the complete damage of spinach field, which, in turn, becomes a source of infestation in other spinaches growing on the same or a neighbouring farm within the same or another season. Influences by the recent increased damage done by Pegomyia hyoscyami, cultivation areas of spinach of foreign races have become narrowed and received considerable degree of financial losses.

Table 1. Number of eggs deposited on five plants of an European race of spinach, Viroflay, which were selected at random in the spinach area near the campus of Kyushu University in the spring of 1945 .

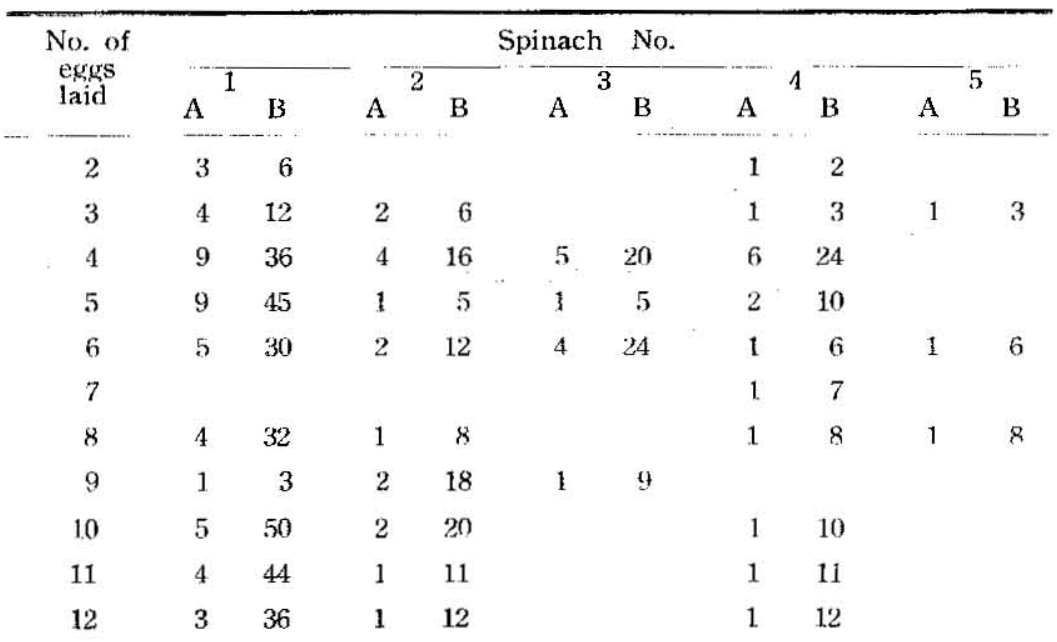




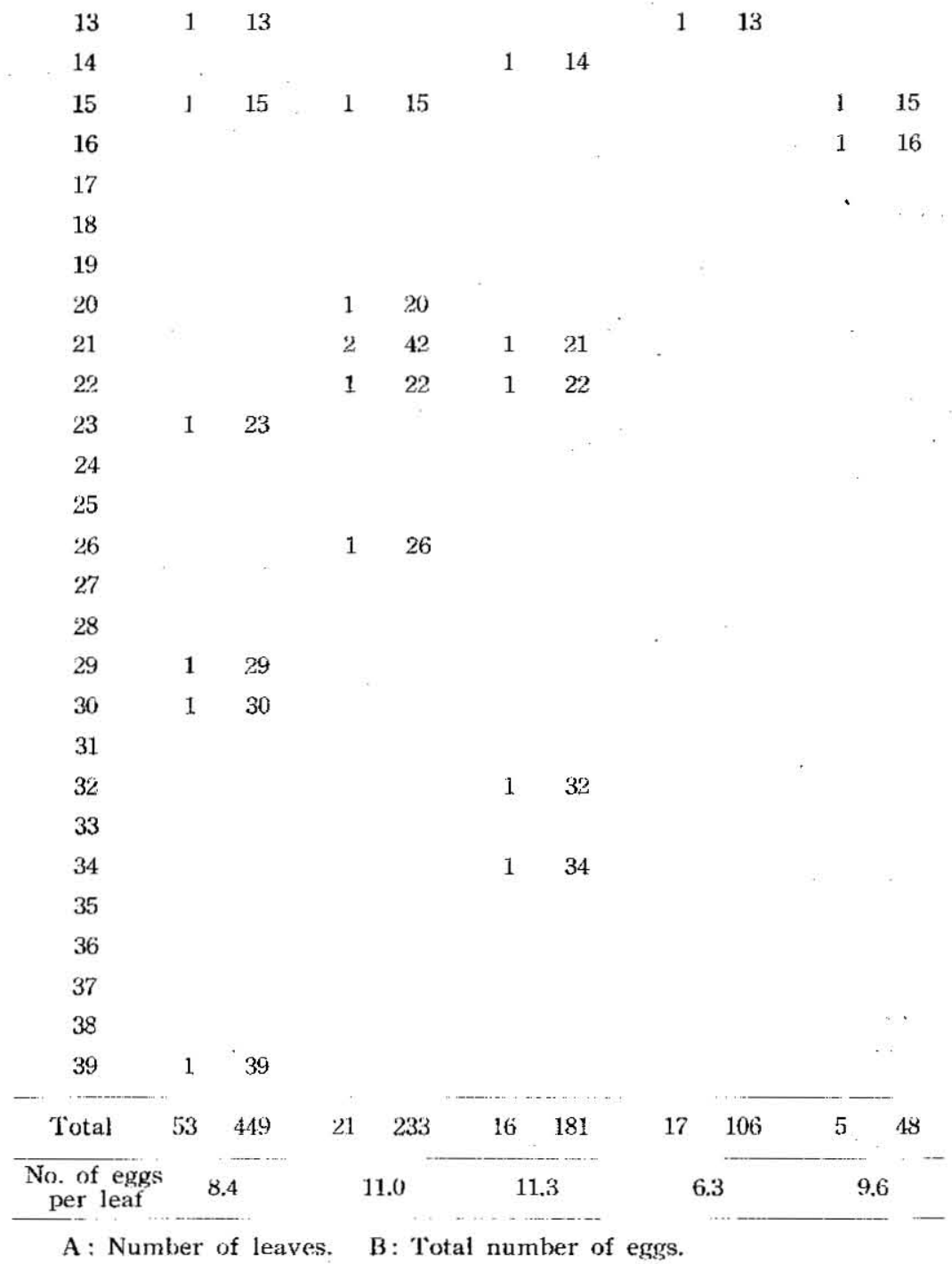

Preoviposttion Perioi) and the Number of Eggs Laid

To ascertain the preoviposition period and the total number of eggs laid by one female, five couples of newly emerged individuals were isolated in pairs and each pair were confined into a separate cage which was provided with fresh spinach leaves, 
and the date and number of eggs laid by each female were recorded. The flies were fed with honey, and the cages containing flies were placed near the window partly so as to receive sunlight. Thus the temperature of each cage was found to be almost equal to that in the field. The record of these observations are shown in Table 2 .

Table 2. Preoviposition period and the number of eggs laid by five mated females of Pegomyia hyoscyami (Observation made in 1943).

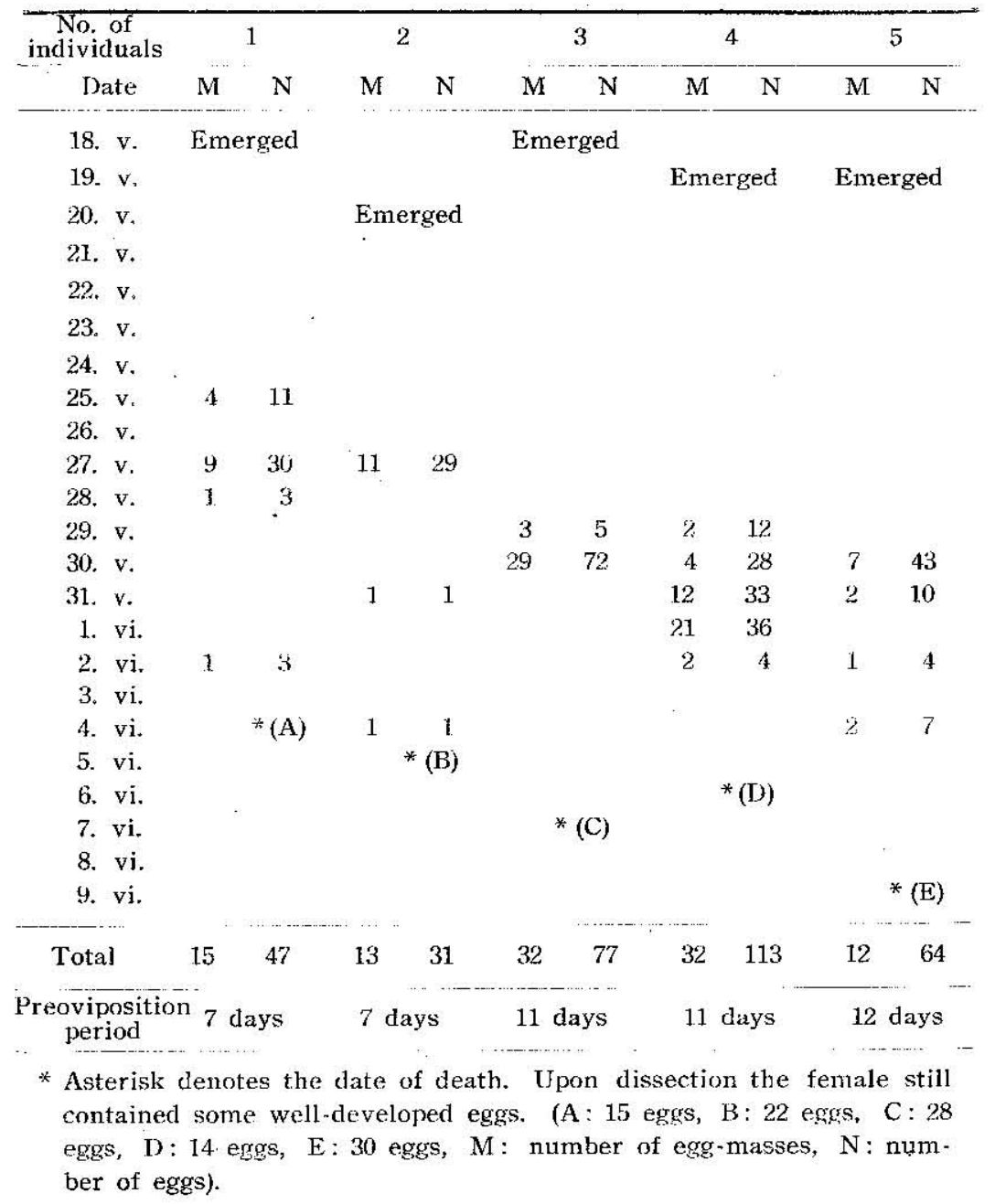


Generally, the mating took place on the day of emergence, sometimes just after emergence. A series of experiments showed that the virgin females or females fed with sugar solution only do not deposit any eggs. The food of the flies in the field is partly the nectar of flowers. As shown in Table 2, the preoviposition period varied about 7 to 12 days. Of course this period has a close connection to the nutrition of the female and the temperature of the environment. For example, Cory (1916) recorded 4 days in U. S. A., and Hille Ris Lambers (1933) observed 5 days in Holland. The maximum number of eggs laid per female was 113 . Zolk (1932) counted 112 eggs which were deposited by a single female in Estonia. According to the experiment made by Bremer and Kaufmann (1931) in Germany, the maximum number of eggs deposited per female was 1.91 under laboratory conditions.

\section{Number of Eggs in a Single Egg-Mass}

Number of eggs in a single egg-mass varies considerably. For example, Vassiliev (1914) in Russia wrote 2 to 12 eggs (average 4-5 eggs) comprising one egg-mass. Rambousek (1925) in Cechoslovakia recorded 1 to 18 eggs in a single egg-mass. Kemner (1925) in Sweden recorded 1 to 12 eggs in an egg-mass. Takiguchi (1948) in Japan reported 1 to 7 eggs comprising one egg-mass. On April, 15, 1945, the authors collected a number of leaves of Chenopodium centrorubrum in the field and observed the number of eggs comprising one egg-mass. The results are summarized in Table 3.

Table 3. Number of eggs in a single egg-mass of Pegomyia hyoscyami.

\begin{tabular}{cccccc}
\hline $\begin{array}{c}\text { No. of } \\
\text { eggs }\end{array}$ & $\begin{array}{c}\text { No. of } \\
\text { egg-masses }\end{array}$ & $\begin{array}{c}\text { No. of } \\
\text { egge }\end{array}$ & $\begin{array}{c}\text { No. of } \\
\text { egg-masses }\end{array}$ & $\begin{array}{c}\text { No. of } \\
\text { eggs }\end{array}$ & $\begin{array}{c}\text { No. of } \\
\text { egg-masses }\end{array}$ \\
1 & 7 & 7 & 25 & 13 & 1 \\
2 & 12 & 8 & 12 & 14 & - \\
3 & 40 & 9 & 8 & 15 & - \\
4 & 58 & 10 & 4 & 16 & - \\
5 & 58 & 11 & 2 & 17 & 1 \\
6 & 40 & 12 & - & & \\
Average & 4.8 eggs per an egg-mass. & & &
\end{tabular}


Host Plan's on Which the Frmale Fiy Delosits Her EgGs

Approximately thirty species of plants have been recorded as hosts of this fly. These plants are distributed in six families, viz., Chenopodiaceae, Solanaceae, Caryophyllaceae, Polygonaceae, Compositae and Rosaceae. The fly has been found to oviposit on six species of plants in Korea and Japan, namely Atriplex subcordata var. japonica (Koidzumi), Beta vulgaris Linné, Beta vulgaris var. Rapacea C. Koch, Chenopodium centrorubrum Nakai, Kochia scoparia Schrader and Spinacia oleracea Linné. Among the races of Spinacia such races as Ujo, Japanese Kairyooba, Jiromaru, Long Standing, Viroflay, Hollandia and Munsterland have been observed to be oviposited and infested. So far as the authors observations go, the fly does not oviposit on the leaves of the Japanese race of spinach. Such races mentioned above are either European, Chinese or hybrids between those and the Japanese races. On April 28th, 1945, a single egg-mass of the fly was found on the leaf of Commelina communis Linne (Commelinaceae) in the spinach field, but the larvae could not continue their normal growth and all died 8 days after hatching. Thus in Northern Kyushu the fly oviposits exclusively on the plants belonging to the family Chenopodiaceae.

As to the relation of Pegomyia hyoscyami to its host plants, Cameron $(1914,1916)$ gave interesting studies. In this connection the authors made the following three experiments, the results of which are summarized in Tables 4,5 and 6 .

Experiment 1: To determine whether adults of Pegomyia hyoscyami, reared from larvae which had fed on the leaves of Chenopodium centrorubrum, would oviposit mainly on the same plant, about 18 mated females were confined in a breeding cage containing potted plants of Chenopodium centrorubrum, Atriplex subcordata var. japonica and the Japanese race of Spinacia oleracea.

Table 4. Number of eggs deposited by Pegomyia hyoscyami females reared from Chenopodium centrorubrum.

\begin{tabular}{cccc}
$\begin{array}{c}\text { Date of } \\
\text { oviposition }\end{array}$ & $\begin{array}{c}\text { Chenopodium } \\
\text { centrorubrum }\end{array}$ & $\begin{array}{c}\text { Atriplex subcorlata } \\
\text { var. japonica }\end{array}$ & $\begin{array}{c}\text { Japanese race } \\
\text { of spinach }\end{array}$ \\
\hline 22. v. & 9 & 6 & 0 \\
23. v. & 18 & 20 & 0
\end{tabular}




\begin{tabular}{lrrr}
$24 . v$. & 11 & 11 & 0 \\
$26 . \mathrm{v}$. & 13 & 14 & 0 \\
$27 . \mathrm{v}$. & 0 & 4 & 0 \\
$30 . \mathrm{v}$. & 0 & 1 & 0 \\
$31 . \mathrm{v}$. & 4 & 2 & 0 \\
\hline Total & 55 & 58 & 0 \\
\hline
\end{tabular}

The differences in the number of eggs deposited on three different plants are significant $(\mathrm{P}<0.01)$. Pegomyia hyoscyami reared on Chenopodium centrorubrum did not oviposit on the Japanese race of spinach.

Experiment 2: To determine whether adults of Pegomyia hyoscyami, reared from larvae which had fed on the leaves of Atriplex subcordata var. japonica, would oviposit chiefly on the same plant, about 36 mated females were confined in a breeding cage containing potted plants of Atriplex subcordata var. japonica, Chenopodium centrorubrum and an European race of spinach, Viroflay.

Table 5. Number of eggs deposited by Pegomyia hyoscyami females reared from Atriplex subcordata var. japonica.

\begin{tabular}{cccc}
\hline $\begin{array}{c}\text { Date of } \\
\text { oviposition }\end{array}$ & $\begin{array}{c}\text { Atriplex subcordata } \\
\text { var. japonica }\end{array}$ & $\begin{array}{c}\text { Chenopodium } \\
\text { centrorubrum }\end{array}$ & $\begin{array}{c}\text { Spinach, } \\
\text { Viroflay }\end{array}$ \\
\hline 22. v. & 11 & 7 & 0 \\
23. v. & 14 & 19 & 0 \\
24. v. & 35 & 14 & 0 \\
25. v. & 29 & 13 & 1 \\
26. v. & 34 & 10 & 0 \\
27. v. & 3 & 6 & 0 \\
28. v. & 0 & 10 & 0 \\
29. v. & 2 & 12 & 3 \\
30. v. & 9 & 10 & 0 \\
31. v. & 0 & 4 & 0 \\
1. vi. & 0 & 3 & 0 \\
Total & 137 & 108 & 4 \\
\hline
\end{tabular}

The differences in the number of eggs deposited on three different plants are highly significant $(\mathrm{P}<0.05)$. 
Experiment 3: To determine whether adult Pegomyia hyoscyami, reared from larvae which had fed on the leaves of an European race of spinach, Viroflay, would oviposit chiefly on the same plant, about 31 mated females were confined in a breeding cage containing potted plants of Viroflay, the Japanese race of spinach and Chenopodium centrorubrum.

Table 6. Number of eggs deposited by Pegomyia hyoscyami females reared from Viroflay.

\begin{tabular}{cccc}
\hline $\begin{array}{c}\text { Date of } \\
\text { oviposition }\end{array}$ & $\begin{array}{c}\text { Spinach, } \\
\text { Viroflay }\end{array}$ & $\begin{array}{c}\text { Japanese race } \\
\text { of spinach }\end{array}$ & $\begin{array}{c}\text { Chenopodium } \\
\text { centrorubrum }\end{array}$ \\
\hline 25. v. & 0 & 0 & 6 \\
26. v. & 5 & 1 & 8 \\
27. v. & 6 & 0 & 14 \\
28. v. & 0 & 0 & 10 \\
29. v. & 4 & 0 & 3 \\
30. v. & 0 & 0 & 8 \\
1. vi. & 2 & 0 & 0 \\
\hline Total & 17 & 1 & 49 \\
\hline
\end{tabular}

The differences in the number of eggs deposited on three different plants are highly significant $(\mathrm{P}<0.05)$. The deposition of one egg on the Japanese race of spinach would be accidental.

As can be seen from Tables 4, 5 and 6, the order of egglaying preference for Pegomyia hyoscyami females is; Atriplex subcordata var. japonica>Chenopodium centrorubrum $>$ European race of spinach, Viroflay. Further it is evident that the fly does not oviposit on the Japanese race of spinach at all or the larvae of this fly cannot complete their life-history in the Japanese spinach. This fact would indicate that the females will not oviposit on the Japanese race of spinach even if host plants are entirely absent in the field.

\section{Reason of Recent Increase in Population of Pegomyia HYOSCYAMI IN NORTHERN KYUSHU}

Observations of the dates of adult emergence of this fly from both field-collected and laboratory-reared puparia indicated that in 1944 adults of the overwintered generation emerged during April 
to the beginning of May, and those of the first generation during the middle to end of May and at the beginning of June and the second generation (Table 7, A) during October to the beginning of November, though some puparia of this generation overwintered and gave rise to adults in the following April--May (Table 7, B). In April and May adult flies can easily find the native host plants for oviposition, viz. Atriplex subcordata var. japonica and Chenopodium centrorubrum, but in the autumn those plants are not available in the field. Therefore flies emerged in September and October cannot oviposit their mature eggs. Thus it is presumably only these overwintered puparia of the second generation that give rise to the spring adults. These relation may easily be recognizable by Table 7 .

Table 7. Life-history of Pegomyia hyoscyami in Northern Kyushu, 1945-1946. : eggs, - : larvae, it : pupae, $O$ : adults.

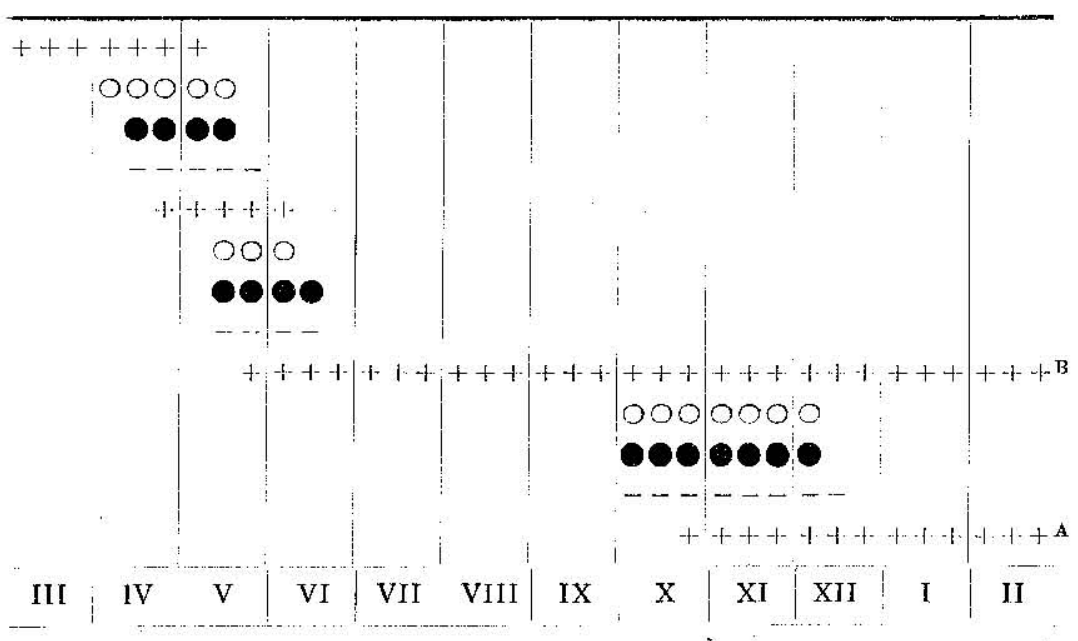

As indicated in the introduction of this paper, Pegomyia hyoscyami has become increasingly troublesome throughout the spinach growing areas of Northern Kyushu since 1939. Namely some time before that year the cultivation of some European and Chinese races or hybrids between European and Japanese races of spinaches was begun. Such spinaches were cultivated in the field from October to the following May. Thus adult flies became to oviposit their eggs both in the spring and autumn. 
This is the reason why populations of this fly have become increased markedly since 1939 .

\section{Distribution of Eggs in the Spinach Field}

In market-garden areas in Fukuoka Prefecture it is the custom to plant spinach in long, comparatively narrow strips. In order to obtain informations on the distribution of Pegomyia eggs, four widely separated areas of spinach were selected. In all instances where this was observed, however, the crops examined were uniform as regards the condition of the plants. Area No. 1 was subdivided into 45 subdivisions of equal size, likewise No. 2 into 25 , No. 3 into 30 and No. 4 into 20 subdivisions respectively. Records of the egg populations on each subdivision were kept and in this way the distribution of eggs could be investigated. The results are shown in Tables 8, 9, 10 and 11 .

Table 8. Distribution of eggs of Pegomyia hyoscyami in the spinach field No. 1 (Observation made in the autumn of 1946).

\begin{tabular}{|c|c|c|c|c|c|c|c|c|c|c|}
\hline \multirow{2}{*}{$\begin{array}{l}\text { Division of } \\
\text { each strip }\end{array}$} & \multicolumn{8}{|c|}{ Strip No. } & & \multirow{2}{*}{$\begin{array}{l}\text { Total no. } \\
\text { of eggs }\end{array}$} \\
\hline & 1 & 2 & 3 & 4 & 5 & 6 & 7 & 8 & 9 & \\
\hline 1 & 3 & 0 & 4 & 3 & 5 & 2 & 4 & 8 & 4 & 33 \\
\hline 2 & 3 & 2 & 4 & 9 & 1 & 9 & 0 & 5 & 5 & 38 \\
\hline 3 & 19 & 5 & 7 & 7 & 10 & 20 & 2 & 2 & 10 & 82 \\
\hline 4 & 9 & 8 & 8 & 3 & 7 & 7 & 4 & 8 & 6 & 59 \\
\hline 5 & 4 & 14 & 7 & 8 & 6 & 2 & 0 & 12 & 17 & 70 \\
\hline $\begin{array}{l}\text { Total no. } \\
\text { of eggs }\end{array}$ & 38 & 29 & 30 & 30 & 29 & 40 & 10 & 35 & 41 & 282 \\
\hline
\end{tabular}

Table 9. Distribution of eggs in the spinach field No. 2.

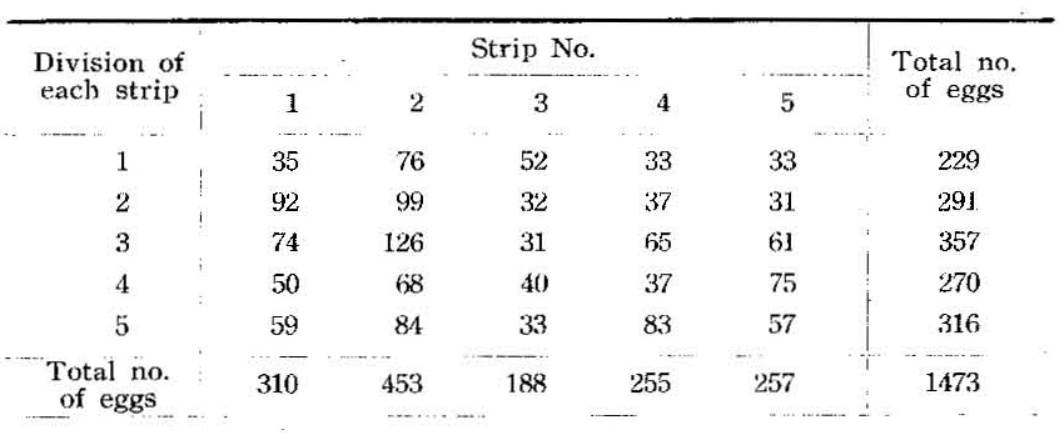


Table 10. Distribution of eggs in the spinach field No. 3 .

\begin{tabular}{c|rrrrrrr|c}
\hline $\begin{array}{c}\text { Division of } \\
\text { each strip }\end{array}$ & 1 & 2 & 3 & 4 & 5 & 6 & $\begin{array}{c}\text { Strip No. } \\
\text { of eggs }\end{array}$ \\
\hline 1 & 32 & 7 & 20 & 0 & 0 & 0 & 59 \\
2 & 0 & 8 & 8 & 1 & 8 & 13 & 38 \\
3 & 0 & 1 & 0 & 0 & 0 & 19 & 20 \\
4 & 16 & 22 & 6 & 1 & 9 & 27 & 81 \\
5 & 6 & 11 & 6 & 14 & 25 & 10 & 72 \\
\hline $\begin{array}{c}\text { Total no. } \\
\text { of eggs }\end{array}$ & 54 & 49 & 40 & 16 & 42 & 69 & 270 \\
\hline
\end{tabular}

Table 11. Distribution of eggs in the spinach field No. 4.

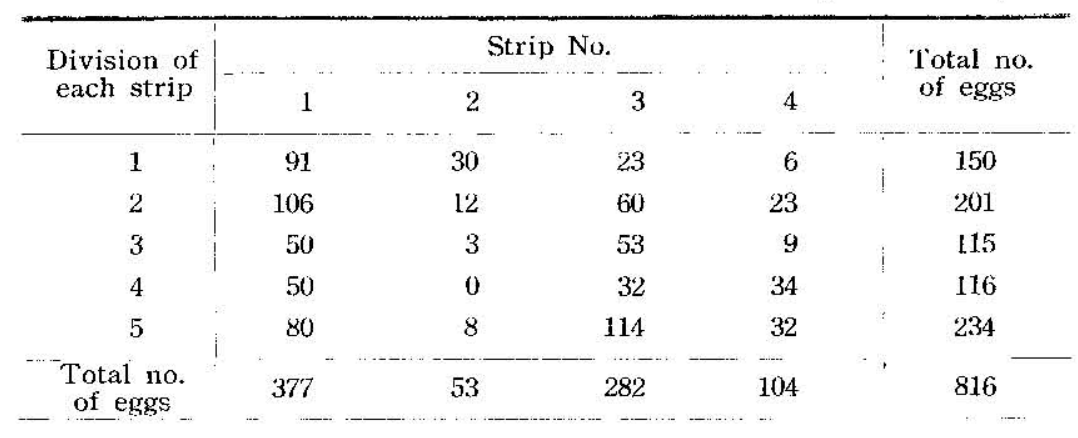

The difference in the number of eggs between the subdivisions is either likely significant or insignificant. It is, therefore, clear that there is no evidence of any tendency of the distribution of Pegomyia eggs in the spinach area. In other words, the adults neither prefer nor select the border or inside of spinach area in depositing their eggs. This fact is most likely to be ascribed to a permanent source of infestation which exists internally to the areas themselves.

\section{Relation Between the Time ol Sowing of Spinach and THE: NUMBER of EgGS LAID}

As to the relation between the time of sowing of spinach and the number of eggs laid by Pegomyia hyoscyami, the authors give summaries of observations made by several entomologists in the following lines. 
Wilke (1922) in Germany :-Early sown beet seems to suffer more than late-sown.

Kleine (1933) in Germany :- The correctness of the practice of late sowing, which is often adopted, is confirmed.

Blunck (1925) in Germany:--Instead of late sowing, advised by Kleine, the author suggests early sowing, so that the plants may not be attacked when yet tender seedlings.

Blunck (1927) in Germany :-Although it is true that late-sown beet remains free from attack by the bect-fly, it is necessary to sow early in North Germany, owing to the losses in weight and sugar-content consequent on late sowing.

Rambousek and Neuwirth (1931) in Czechoslovakia:- In two adjoining fields beet sown late escaped injury, whereas that sown early was severely infested.

Roebuck, Baker and White (1945) in England:--Infestation by the first generation was avoided if sowing was delayed until mid May in 1945, such late-sown crops were not attacked to any extent by the later generations.

In order to ascertain whether such relation may exist also in Northern Kyushu, the following field experiment was undertaken. In the spring of 1947 seeds of Viroflay were sown side by side in four narrow strips in four different dates (March 15, March 25, April 4 and April 14) before emergence of adult flies of the overwintered generation, and the date and number of eggs laid by Pegomyia hyoscyami were recorded. The results are shown in Table 12.

Table 12. Number of eggs of Pegomyia hyoscyami deposited on four groups of spinach plants which were sown in narrow strips side by side at different dates in 1947 .

\begin{tabular}{ccccc}
\hline $\begin{array}{c}\text { Date of } \\
\text { oviposition }\end{array}$ & 15. iii. & 25. iii. & 4. iv. & 14. iv. \\
\cline { 2 - 5 } & 13 eggs & 0 & 0 & 0 \\
\hline 26. iv. & 19 & 0 & 0 & 0 \\
27. iv. & 18 & 0 & 0 & 0 \\
28. iv. & 14 & 0 & 0 & 0 \\
29. iv. & 0 & 9 & 0 & 0 \\
30. iv. & 0 & 1 & 12 & 0 \\
1. v. & & & &
\end{tabular}




\begin{tabular}{rrrrr}
3. v. & 0 & 4 & 3 & 0 \\
4. v. & 2 & 14 & 3 & 0 \\
5. v. & 0 & 6 & 0 & 0 \\
6. v. & 0 & 3 & 0 & 0 \\
8. v. & 3 & 0 & 2 & 0 \\
12. v. & 2 & 0 & 12 & 0 \\
14. v. & 0 & 4 & 0 & 2 \\
\hline $\begin{array}{c}\text { Total no. } \\
\text { of eggs }\end{array}$ & 71 & 51 & 22 & 2 \\
\hline
\end{tabular}

Thus the results have clearly shown that the number of eggs deposited on the leaves of spinach by the adult flies depended upon the time of sowing of its seeds. Attention must here be called that the larger the leaves the more the eggs or the younger the plants the fewer the eggs.

\section{RÉSUMÉ}

Hitherto not a single detailed observation on the egg-laying habits of Pegomyia hyoscyami Panzer has been performed in Japan. The present investigations have been carried out near and in the campus of the Kyushu University, Fukuoka, Northern Kyushu, during 1943-1947. The results are set out in nine chapters given above. The most important conclusion to be derived from the authors' investigations is the fact that the fly does not oviposit on the leaves of the Japanese race of spinach and the cultivation of some European, Chinese or hybrids between those and the Japanese races initiates a marked increase in its population. Some bearing of the results on measures for controlling this fly will be evident to any one who reads the contents. 


\section{LITERATURE}

Balachowsky, A. et L. Mesnil 1936 Les insectes nuisibles aux plantes cultivées, leurs moeurs, leurs destruction. Paris.

Blunck, H. 1925 Der Stand der Riibenfliegenfrage. Mitt. rltsch. Landw.-Ges., $125: 480-484$.

Blunck, H. 1927 Der Stand der Rübenfliegenfrage im Jahre 1926. Deutsche Zuckerind., $52: 17-20$.

Blunck, H., Bremer, H. und O. Kaufmann 1929 Untersuchungen zur Lebensgeschichte und Bekämpfung der Rübenfliege (Pegomyia hoyoscyami Pz.). 9. und 10. Mitteilung. Arb. biol. Reichsanst., 16, Nr. 2 : 103-224.

Bremer, H. und O. Kaufmann 1931 Die Rübenfliege Pegomyia hyoscyami Pz Monogr. Pflanzenschutz, Nr. 7, V+110 pp.

Cameron, E. 1914 A contribution to a knowledge of the belladonna leaf-miner, Pegomyia hyoscyami, Panz., its life-history and biology. Ann. Appl. Biol., 1, no. $1:$ :33-76.

Cameron, E. 1916 Some experiments on the breeding of the mangold fly (Pegomyia hyoscyami, Panz.) and the dock fly (Pegomiya bicolor, Wied.). Bull. Ent. Res., 7, no. $1: 87-92$.

Cory, E. N. 1916 Notes on Pegomyia hyoscyami, Panz. Jour. Econ. Ent., 9, no. $3: 372-375$

Hille Ris Rambers, D. 1932 Gegevens over biologie en bestrijding der bieten vlieg. II. Meded. Inst. Suikerbietenteelt, 2 : 163-214.

Hille Ris Rambers, D. 1933 Gegevens over biologie en bestrijding der bietenvlieg. III. Meded. Inst. Suikerbietenteelt, $3:$ 111-120.

Huckett, H. C. 1941 A revision of the North American species belonging to the genus Pegomyia (Diptera: Muscidae). Mem. Amer. Ent. Soc., no. 10, 131 pp.

linms, A. D. 1915 Notes on beet or mangold fly. Jour. Bd. Agric., London, 22 , no, $9: 881-884$.

Kato, S. 1941 Taxonomic notes on Pegomyia hyoscyami Panzer (Dipt., Muscidae) and its allied species in Nippon (In Japanese). Kontyû, 15, no. 2:55-68.

Kemner, N. A. 1925 Betflugen (Pegomyia hyoscyami Pz.) och det stora betflugang reppet 1924. Meddelande $\mathrm{N}: 0288$ frăn Centralanstalten för försöksväsendet pă jordbruksomrădet, Entomologiska Avdelningen, N:0 47.

Kleine, R. 1923 Die Runkelfliege (Pegomyia hyoscyami, Panz.) und die land wirtschaftliche Praxis. Blätter Zuckerrübenbau, 30:1-23.

Kuwayama, S. 1938 Report on the distribution of insects injurious to the more important crops and their state of infestation in Manchoukuo (In Japanese). Manshukoku Sangyobu Shiryo, $33: 50$.

Oda, F. 1939 A part of vegetable pests in Takimoto and Odas' "Vegetable diseases and pests" (In Japanese): 255. Tokyo.

Rambousek, F. 1925 Schädigungen und Krankheiten der Zuckerrübe vom 19 Mai bis 24 Juni 1925. Prager Zuckermarkt, Beilage z. Zeitschr. Zuckerind. cechosiow. Republ., 49 : 414-415, 425, 433, 450-451, 459-460.

Rambousek, F. \& F. Neuwirth 1931 Př̀ispěvek k epidemiologie mouchy burákové. Ochr. Rost., $11: 158-167$. 
Roebuck, A., Baker, F. T. and J. H. White 1945 Observations on the biology and experiments on control of the mangold fly (Pegomyia betae Curtis) on sugar beet. Ann. Appl. Biol., 32, no. $2: 164-170$.

Takiguchi, M. 1948 Notes on Pegomyia hyoscyami Panzer var. betae Curtis, a pest of the spinach in Fukuoka Prefecture (In Japanese). Fukuoka Agric. Exp. Sta., mimeographical printing, $24 \mathrm{pp}$.

Thorp, W. H. 1930 Biological races in insects and allied groups. Biol. Rev., 5, no. $3: 177-212$.

Vassiliev, Eug. M. 1914 Report on the work of the Experimental Entomological Station of All-Russian Society of Sugar- Rifiners in 1913. Kiev.

Vassiliev, Eug. M. 1915 The control of Pegomyia hyoscyami, Panz. Herald of the Sugar Industry, Kiev, no. $25: 598-590$.

Wilke, S. 1922 Die Runkel- oder Rübenfliege (Pegomyia hyoscyami, Panz.). Beilage, Nachrichtenblatt deutsch. Pflanzenschutzdienst., Berlin, II, Nr. 9.

Yokoo, T. 1940 On the morphology and distribution of three Anthomyidae as important pests of vegetable crops in Korea (In Japanese). Oyo-DobutsugakuZasshi, 12, nos. 5 et $6: 187-208$.

Zolk, K. 1932 Das Vorkommen der Rübenfliege (Pegomyia hyoscyami Panz.) in Estland und einige über ihre Bionomie. Mitt. Versuchssta. angew. Ent. Univ. Tartu, Nr. 16, 16 pp. 